Questions de communication

$24 \mid 2013$

Renouvellement des mises en scène télévisuelles de la politique

\title{
What Renewal for TV staging of Politics
}

\section{Pierre Leroux and Philippe Riutort}

Translator. Inist

\section{OpenEdition}

\section{Journals}

Electronic version

URL: http://journals.openedition.org/questionsdecommunication/8892

DOI: 10.4000/questionsdecommunication.8892

ISSN: 2259-8901

\section{Publisher}

Presses universitaires de Lorraine

\section{Printed version}

Date of publication: 31 December 2013

ISBN: 978-2-8143-0182-5

ISSN: 1633-5961

\section{Electronic reference}

Pierre Leroux and Philippe Riutort, «What Renewal for TV staging of Politics », Questions de communication [Online], 24 | 2013, Online since 01 February 2014, connection on 20 April 2019. URL http://journals.openedition.org/questionsdecommunication/8892 ; DOI : 10.4000/ questionsdecommunication.8892

This text was automatically generated on 20 April 2019

Tous droits réservés 


\title{
What Renewal for TV staging of Politics
}

\author{
Pierre Leroux and Philippe Riutort
}

Translation : Inist

\section{EDITOR'S NOTE}

This English translation has not been published in printed form/Cette traduction anglaise n’a pas été publiée sous forme imprimée.

1 Apart from some very rare and brief exceptions, until the end of the 1990 s the representation of political personalities was staged under the control of journalists and newsroom editorial boards. Politics remained the preserve of a small number of recognized professionals who shared the same "vision and division" framework references (Boltanski, Bourdieu, 1976) of politics as theipoliticians they interviewed. In other words, they had a shared overall idea of the media representation of politics which referred back to an ideal type of exchanges centred on arguments put forward by the main figures of representative democracy to people with contradictory standpoints or who ask questions (political opponents and and/or journalists, then more recently ordinary citizens supervised by journalists). This domination of logos (Lochard, Soulages, 2003) had already begun to dwindle and this became even more the case at the end of the 90 s with the regular appearances of "politics professionals" on the first "conversational shows"1.

2 From the outset, these programmes assert that their aim is to desacralize politics and therefore include political personalities in shows specifically aimed at audiences who are a priori the least interested in politics. To examine these new frameworks for the reception of political figures and the possible transformations of political discourse, the first analyses focused above all on the many elements which distinguished these shows from the more classical political shows which came before by particularly highlighting (using comparisons) their low level of political influence on politics ${ }^{2}$. At the outset, 
certain elements support this thesis, for example less politicians being invited than entertainment personalities, a clear tendency to "de-politicize" discourse which decreased its political effect, a small amount of media picking up on the political opinions put forward in these programmes (Leroux, Riutort, 2011) which could to the conclusion that they are relatively vacuous from a political standpoint. In the previous state of the political/entertainment shows ratio, this point of view seemed relatively relevant even if since the 80 s the hybridization of programmes had already greatly redefined the scope of political shows (particularly with the presence of guests from outside the political sphere) 3. However the ways in which conversational shows have evolved has largely made some of these distinctions obsolete. Right from the start, entertainment show promoters saw themselves as competing with journalists while many indicators show that the shows' presenters had a certain success in redefining statuses. Presenters managed to bring to light alternative approaches to political representation which were unhindered by the political objectives journalists often put forward (shedding light on democratic decisionmaking) and more defined by an entertainment-based objective (insofar as the idea is to integrate politics and politicians into television entertainment $\left.{ }^{4}\right)$. Television's political history (Bourdon, 1994; Olivesi, 1998) has meant that French television was the last media to manage to preserve the way in which politics was portrayed from any change while other media (radio, the press, etc.) had greatly weakened distinctions through methods of coverage, approaches or centres interest ${ }^{5}$. Conversational shows thus take their place in a general movement of aggiornamento in the way the media covers politics. These shows could not have changed television's relationship with politics on their own even if they have indeed contributed to bringing about change in the television frameworks for staging politics by integrating the desacralization of politics in the public media space. The continually increasing numbers of recognized journalists talking part in entertainment shows (very widespread nowadays) has probably played a decisive role in these being recognized both in symbolic and practical terms. Consequently, the dividing line between entertainment and classical political shows has become increasingly blurred and all kinds of programmes can claim, with varying degrees of success, to contribute to constructing public debate.

\section{Characterizing political entertainment shows}

3 In France it was only in the 90s that the first entertainment shows on private and public channels began to invite political personalities. Although people in politics had never - even in the era of the French public television monopoly - just been present on political shows $^{6}$, these new programmes introduced a kind of break in the televisual representation of politics. They can be defined based on three characteristics. Firstly these programmes are under the control of the channel's programme management departments (and not newsrooms) and are therefore often produced and hosted by television presenters (rather than journalists). This has meant that these shows take the liberty of freeing themselves from the rules and codes which previously regimented television's relationship with politics (Mouchon, 1998). The professional elite of TV show hosts - a profession which became a vital element when commercial television took the upper hand in France in the middle of the 80s (Leroux, Riutort, 2006) - were thus able to symbolically enhance their position because access to the political sphere had previously been the last preserve of journalists. Crossing this dividing line offered new perspectives, 
particularly the pretension that presenters make a civic contribution to democratic debate which would have been unimaginable in television beforehand (ChalvonDemersay, Pasquier, 1990). A second characteristic is that these programmes integrate political figures into the very construction of the show in an explicit and regular manner. Politicians have become a permanent ingredient in such shows while remaining in the minority as far as guests are concerned (unlike political shows) but nonetheless becoming something of an unquestionable fixture. Finally the third characteristic is that these shows are not specifically designed for politicians. They need to fit into a construction (or "dispositif" as in Foucault's work) ${ }^{7}$, the logic of which is foreign to the political universe and into debates on public affairs in shows based partly on codes of entertainment long developed to host show business guests. Political discourse thus finds itself in a very different place in conversational shows from in political shows or news programmes. Politics is no longer necessarily in a state of supremacy and is confronted as never before with permanent sources of interference intended to act as a tool for destabilization with varying degrees of violent and explicitness according to the shows' formulas. Such formulas depend on specific constraints linked to the time of screening, the potential audience and the format. Certain roles are attributed to the audience (who are inevitably reactive, enthusiastic and seeking spectacular events ${ }^{8}$ ), the show's main host and his or her acolytes (commentators and snipers known for their talent for reactivity and unnerving phrases), the various sequences which give rhythm to the programme (which in practice actually contradict conventional forms of political discourse) and possibly later editing (if the programme is not broadcast live). All these factors contribute to constructing a spectacle which continually renews itself, more effectively avoiding tunnels , abstruse speeches and arguments which journalists in more classical formulas of debate and exchange would not have allowed themselves to develop'.

Television show hosts therefore began screening the first entertainment-based shows including political guests in varied formats. Le Vrai Journal (Canal +, 1996-2006) included an interview of around ten minutes (cut from a real 45 to 60-minute interview) with a political figure in a programme, made-up (real) reports and parodies; Vivement dimanche (France 2, 1998-the present) ${ }^{10}$ invites politicians to reveal something of their private lives as the main guest - a formula previously reserved for show business personalities (biography, tastes, "hidden side" of personalities) and Tout le monde en parle (France 2, 1998-2006) quickly adopted the formula of an interview on the TV set with a political personality at a table alongside guests from show business. This format has been a template - with numerous variants - pour other shows like On ne peut pas plaire à tout le monde (France 3, 2000-2006), T'empêches tout le monde de dormir (M6, 2006-2008), Vendredi et Samedi pétantes (Canal +, 2003-2006), Le Grand Journal (Canal +, 2004-) and On n'est pas couché (France 2, 2006-), all of which have contributed to the general acceptance of this way of portraying politics.

\section{Time to take stock?}

5 From the start in France the novelty of these ways of staging politics led to a lot of questions and protests regarding the transformations of the representational frameworks of politics "seized by entertainment " (Coulomb-Gully M., Tournier M., 2001; Reseaux, 2003). Do these shows lead to the marginalization or even the definitive decline of traditional forms of staging politics hosted by journalists? The question was asked and 
this alarmist point of view argued by political journalists and certain observers of television: "The Americanization of political life", the "victory of the spectacular", the "consecration of infotainment" were all evoked and the politics/entertainment mix was said to be partly responsible for a general "crisis" of democracy. By situating these shows in a larger overall movement (Sartori, 1989) and in the context of broader reconfigurations of the representation of politics, the break with the past they introduced can be put into perspective to better situate their true mechanisms and stakes. In France, Erik Neveu (1995) very quickly defined markers to help situate the emergence of political professionals' new frameworks for expression in a continuity - the "dead ends" (Neveu, 1995) or even "the failure" (Coulomb-Gully, Tournier, 2001) of the televised spectacle of political speech in political shows should logically have led to forms of renewal and the model of the United States could logically have inspired French professionals ${ }^{11}$. The same author also situates critical analyses of these transformations in the framework of research work abroad which firstly enable the implicit identification of specific features of the French landscape and also the common basis for certain ideological oppositions which underpin analysis and debate ${ }^{12}$. Regarding discourse and how it has been transformed, the "neo-television" revolution (Casseti, Odin, 1990), the relationship with the private sphere (Mehl, 1996) and more specifically of political speech (Lochard, Soulages, 2003) also underline continuities. Changes to political discourse are part of more general transformations of the way people speak on television and this broadening of focus enables us to truly take stock of the originality of how politicians' appearances are staged on entertainment shows.

6 Reference to these works helps situate the aim of this file which is to question the political/television articulation through these forms of televisual representation. In other words, as conversational shows have become a fixture on French television (they have existed for around fifteen years), it is worth asking what helped them last so long and gain a permanent place in the way politics is stages in the media. The main political figures (practically the sole guests invited for the major occasions on television) considered that taking part in the classic political shows was - and still is - a democratic duty informed by their belief in the ability of such platforms to interest and convince citizen-viewers but the point of taking part in entertainment shows and their political usefulness did not initially seem self-evident at least beyond particular cases and the more general reasons (becoming well-known, reaching a wider audience) ${ }^{13}$ which are often put forward. However these more general objectives are not initially shared by all members of the political classes. In fact, the risk element inherent in the very forms of these shows requires talents which are used to a lesser extent in daily political life and might also have caused problems for the long-term success of these "new" tribunes. Nonetheless, currently the novelty effect has worn off and it is still clear that these shows have become widely accepted as part of both television and political life. These shows make an contribute significantly to making politics visible and accessible for a broader audience by inviting most major political figures and through the media echo of those appearances. Their presence in the 2012 French presidential election campaign looked lot like an effect of their institutionalization ${ }^{14}$ as a political tribune of a specific genre and took place without in-depth debate or criticism of the channels that screened them. Talk-shows - the generic term - with political guests ${ }^{15}$ were a much more central part of the election campaign which had not previously been the case, notably during the run-up to the 2007 presidential election (they were either cancelled or their choice of guests was limited). 
They invited the candidates and their representatives to appear and they complied with rules regarding the representation of the political field set out by the television authorities ${ }^{16}$. To understand this success, we need to look at the dynamic of evolution of these shows. A linear description of this institutionalization cannot be given which is why a study of the politics/television articulation seems necessary and relevant. Show formulas have profoundly changed and as well as schedule changes (only Vivement dimanche has survived to the present and Le Grand Journal has now been on screen for ten years), shows have continuously needed to rethink their relationships with politics. Although the conversational formula seems to have become a fixture in the schedules ${ }^{17}$, the internal mechanics of these shows are now very different from when the shows began. Political guests have become the norm but this has required many adjustments and concessions to the political universe along with innovations and elements borrowed from other relationship modalities regarding politics which define whether the show is a failure or a success in the audience ratings. These show the malleability of a genre as well as its capacity to adapt. If we wish to measure the possible effects of these shows on political representations, this should probably not be analyzed as an overall victory for entertainment in staging of politics (which hardly means we can conclude that a model has been imported from the United States where for many years these shows have had a major place in the schedules - comparable to other types of classic political shows). The classic political show formulas have not disappeared - they have found themselves a new place which may not be comparable to the place occupied by the major political events on television in the past, although this is more due to the increase in programmes on offer ${ }^{18}$ than to competition from the added competition of entertainment shows with political guests. Conversational shows are thus part of an increased offer of shows staging politics which can attract relatively large audiences without making any differences to the audience ratings of more conventional political shows which in this respect are affected by the vagaries and major events of political life ${ }^{19}$. The specific nature of today's conversational shows therefore needs to be examined.

7 The politics/entertainment articulation is discussed in several articles in this file. The authors of the first article return to the question of political figures taking part in entertainment shows. Pierre Leroux and Philippe Riutort note that political activity as a field exists through a certain number of positions, interests and individuals' possessed capital and go on to discuss political figures' relationship with entertainment-based scenes to situate that relationship within a dynamic of evolving forms and discourse. The authors' starting point is the question of the "invitation" implicitly sent to politicians by presenter-producers of entertainment shows and they then attempt to understand how the participation of the main political leaders in shows with different formulas works in real terms over time but in a differentiated manner according to the programmes concerned. How do the promoters of these programmes manage to impose new modes of representation of politics? What tensions reveal the difficulties of varying degrees involved in gaining access to the political universe? The authors show that studying the power struggle between these programmes and their participants is the best way to understand how the shows gradually become legitimate.

8 This general discussion of such questions continues with the work of Benoit Lafon who studies the motives and communicational strategies of media and political figures by focussing on the case of the appearance by the leader of the Nouveau Parti anticapitaliste (NPA, New Anticapitalist Party) Olivier Besancenot on the variety show 
Vivement dimanche presented by Michel Drucker in May 2008. This show is considered emblematic of new forms of political communication (and of the construction of a political identity strongly based on personality traits) and is sometimes considered to possess an incomparable ability to positively promote political figures and their performances on the show which directly translate into favourable election results ${ }^{20}$. The low number of politicians invited onto this Sunday show each year (compared with the show business stars the programme is constructed around) and the resulting selectiveness therein have both contributed to its renown. Appearances on the show quickly became much sought after by politicians following the first political guests and is considered by commentators as a calmer kind of entertainment show (politicians just need to show themselves as they really are). Benoit Lafon shows that it is less revealing to focus on the show's supposed merits and powers and that beyond the apparently simplicity of content, appearances on the show borrow from many registers (not just entertainment) and involve other stakes. Vivement dimanche gives rise to intense journalistic activity and is analysed by the author as an investment in and on the political market on both the political and journalistic levels. The benefits in terms of media echo for a political figure taking part in the show, a new form of "trap for hermeneuts" (Champagne, 1990), are thus viewed - at least as much as the ratings - as an indicator of the person's political importance and helps make political figures more noteworthy.

Next Patrick Amey analyses the specific discourse and staging of politics in another emblematic conversational show, Le Grand Journal (Canal +). In 1984, the show took the place of another live on-set show (Nulle Part ailleurs) which only dealt with politics indirectly (mainly with its "Spitting Image" style parody of a news show Les Guignols de l'info). Le Grand Journal gradually shaped the spaces for the reception of politics and gained access to political figures of the highest level, thus managing to become virtually the unique reference in terms of French infotainment. Taking inspiration from models from other countries, Le Grand Journal was a new departure for such shows with its specific framing of politics seemingly able to preserve politics from the getting too close to the world of show business while still including it in a common overall system. As the study (carried out on a corpus of shows broadcast in 2009) shows, the way political speech is framed by this construction (or "dispositif") constructs frameworks for the interpretation of actions and political personality. The author relates a key period for the show when the most harmful humorous content for politics was cut and the framing of politics thus took on a whole new dimension. The way the show changed later highlights the accuracy and relevance of the researcher's analysis. The autonomy given to the Petit Journal (in September 2011) and importance accorded to "La petite question" (a question asked live on the set) confirms the success of the Grand Journal's approach as far as ratings are concerned of course but also its popularity with political figures as an "unmissable space" for a form of representation of which Patrick Amey analyses the ambiguous nature.

10 Frederick Bastien and David Dumouchel carried out a study into the Quebec version of the French show Tout le monde en parle (Radio-Canada) presented in Canada by Guy A. Lepage. This version uses elements from the French show presented by Thierry Ardisson and was compared here to Téléjournal. It is a valid extension to the French case and questions the specificity of the way politics is handled in entertainment shows. The study covers a period during the election campaign taking as its starting point the hypothesis of a significant level of differentiation between the ways of interviewing politicians in television news shows and in Tout le monde en parle and the researchers found an absence 
of significant differences. The indicators used to evaluate the respective levels of rigorous questioning (types of questions) and the subjects discussed (what is at stake, strategy, private life, personality) were found to follow the same kind of direction. Few differences were found in the ways of working of journalists and presenters and the traditional spectrum of subjects (including the political stakes for entertainment shows and private life for journalists) seems to invalidate the hypothesis of roles being shared between entertainment and journalistic work.

11 The last article deals with the emblematic case of the United States where talk-shows occupy a large space in terms of quantity than in France. US talk-shows are supposed to be a model and most often in negative terms. Jeffery P. Jones' text is particularly interesting because it re-situates the very singular situation in the United States. In the States, there have been non-stop news channels for much longer, political satire shows with political guests have become institutionalized and afternoon talk-shows have more influence which all goes to make up a very different landscape from that of France. Thus it would seem that American talk-shows are far from being homologous with their French counterparts and are in fact more "political" (as is the case of shows on Fox News which have become true political tribunes), "entertainment based" (in the sense that in the States there is much less resistance to entertainment) and "popular" (afternoon talk-shows are specifically aimed at women from the popular classes which is a notable difference from French shows of the same type).

\section{Conclusion}

The analyses in this file cover a spectrum of subjects which may not be exhaustive but are still sufficiently broad in scope to enable conclusions to be drawn regarding how politics is handled in entertainment show in general. They highlight three phenomena: 1) a dynamic of evolution of the way politics is framed which is not limited to entertainment shows; 2) less differentiation than in the past between the journalists' and presenters' approaches to politics; 3) overall television repositioning itself with regard to politics. There is no doubt that in the years to come these in-depth movements will lead to changes in the forms and discourse and in the relationships the media has with the representation of politics.

\section{BIBLIOGRAPHY}

Boltanski L., Bourdieu P., 1976, «La production de l'idéologie dominante », Actes de la recherche en sciences sociales, 2/3, pp. 4-73.

Bourdieu P., 1995, « Champ politique, champ des sciences sociales, champ journalistique. Cours du Collège de France prononcé le 14 nov. 1995 à l'université Lumière Lyon 2 », Cahiers de recherche , 15.

Bourdon J., 1994, Haute fidélité. Pouvoir et télévision. 1935-1994, Paris, Éd. Le Seuil. 
Brants K., 2003, « De l'art de rendre la politique populaire. Ou “qui a peur de l'infotainment ?" ", Réseaux, 118, pp. 135-166.

Casseti F., Odin R., 1990, « De la paléo à la néo-télévision. Approche sémio-pragmatique », Communication, 51, pp. 9-26.

Chalvon-Demersay S., Pasquier D., 1990, Drôles de stars. La télévision des animateurs, Paris, Aubier.

Champagne P., 1990, Faire l'opinion. Le nouveau jeu politique, Paris, Éd. de Minuit.

Coulomb-Gully M., Tournier M., 2001, « La politique à l'écran : l'échec ? », Mots. Les langages du politique, 67, pp. 3-7.

Darras É., 1999, « Télévision et démocratisation. La "télévision forum” en France et aux ÉtatsUnis », pp. 61-84, in : François B., Neveu É., dirs, Espaces publics mosaïques, Rennes, Presses universitaires de Rennes.

- 2005, « Permanences et mutations des émissions politiques en France », Recherches en communication, 24, pp. 109-128.

Eschstruth I., 2007, « La politique et le pluralisme à la télévision à l'épreuve des chiffres du CSA ». Accès : http://www.acrimed.org/article2647.html. Consulté le 16/09/13.

Le Foulgoc A., 2007, Les représentations politiques reconfigurées par le divertissement à la télévision française. Des programmes pris dans des stratégies et des temporalités, thèse en sciences de l'information et de la communication, université Panthéon-Assas.

Lefébure P., 2005, Quand les citoyens discutent le lien représentatif, thèse en science politique, Institut d'études politiques de Paris.

Leroux P., Riutort P., 2006, «La consécration de l'animateur. Appréciation d'un métier et affirmation d'une position : les métamorphoses de Thierry Ardisson », Réseaux, 139, pp. 219-248.

- 2011, « Les émissions de divertissement : de nouveaux lieux de valorisation des petites phrases », Communication \& langages, 168, pp. 69-80.

Lochard G., Soulages J.-C., 2003, «La parole politique à la télévision. Du logos à l'ethos », Réseaux, 118, pp. 65-94.

Malherbe A. de, 2007, Politiques recherchent audimat désespérément, Paris, A. Michel.

Mehl D., 1996, La télévision de l'intimité, Paris, Éd. Le Seuil.

Mouchon J., 1998, La politique sous l'influence des médias, Paris, Éd. L’Harmattan.

Nel N., 1998, « Les dispositifs télévisuels », pp. 59-73, in : Bourdon J., Jost F., éds, Penser la télévision, Paris, Nathan.

Neveu É., 1995, « Les émissions politiques à la télévision. Les années quatre-vingt ou les impasses du spectacle politique », Hermès, 17-18, pp. 145-162.

- 2001, « Une crise de la parole politique à la télévision. Échos d'un débat anglophone », Mots. Les langages du politique, 67. pp. 8-27.

- 2003, « De l'art (et du coût) d'éviter la politique. La démocratie du talk-show version française (Ardisson, Drucker, Fogiel) », Réseaux, 118, pp. 95-134.

- coord., 2003b, « La politique saisie par le divertissement », Réseaux, 118.

- 2012, « Prosaïser le politique ou politiser le prosaïque », in : Amey P., Leroux P., dirs, 2012,

L'échange politique à la télévision. Interviews, débats, et divertissements politiques, Paris,

Éd. L'Harmattan. 
Olivesi S., 1998, Histoire politique de la télévision, Paris, Éd. L'Harmattan.

Rouquette S., 2001, L'impopulaire télévision populaire. Logiques sociales, professionnelles et normatives des palabres télévisées (1958-2000), Paris, Éd. L'Harmattan.

- 2002, Vie et mort des débats télévisés, Paris/Bruxelles, Ina/De Boeck.

Sartori G., 1989, « Video-Power », Government and Opposition, 1, vol. 24, pp. 39-53.

Van Zoonen L., 2004, Entertaining The Citizen: When Politics and Popular Culture Converge, Lanham, Rowman \& Littlefield.

\section{NOTES}

1. The phrase "conversational shows" refers to shows based around the codes of ordinary conversation in their form (interruptions, changing subjects, multiple interactions) as well as in their content (low level of hierarchy among participants, emphasis on the quality of replies, humour etc.) as opposed to political shows designed to put forward arguments expressed using traditional forms of political rhetoric. In his contribution to the file, Jeffrey P. Jones also underlines this aspect (for American talk-shows) which combines conversation and interpersonal exchanges with the mediatised show. However this is a general dominant characteristic of such shows although there are numerous variations thereof according to the formula. In these shows, the idea is less for people to "give their vision of the political world as if it was based on objectivity" (Bourdieu, 1995) than to establish a dynamic of rapid exchanges where the place of political discourse is not a priori defined as the dominant factor (unlike show whose programmers define them as "political").

2. Aurélien Le Foulgoc (2007) considers conversational shows to be "out of context"; Erik Neveu (2003) discusses the way politics is sidelined while Éric Darras (2005) underlines the important effect of political declarations picked up from political shows as compared to the quasi-nonexistent effect of statements made in entertainment shows.

3. Among the French TV programmes which derived from this politics/entertainment hybridization, we may cite Sept sur Sept (TF1), Les Absents ont toujours tort (La Cinq), L'Hebdo (Canal + ) and many of the political shows of the 2000s such as 100 minutes pour convaincre (France 2) or À vous de juger (France 2) which respectively had $39 \%$ and $45 \%$ of non-political guests (Le Foulgoc, 2007) with celebrities, experts or possibly unknowns on screen.

4. The fact that the three first entertainment shows to be broadcast (Le Vrai journal, Vivement dimanche and Tout le monde en parle) were pre-recorded testifies to the spectacular scope they aimed for - to accelerate the rhythm of exchanges and unburden political discourse of its "down time" namely mostly elements which might link up themes and discourse in classical political shows.

5. Examples of the blurring of lines between aims based on politics and entertainment are morning radio news shows, the emblematic Paris Match among magazines and also more general changes which have affected the media along with the specific and multiple modalities used to cover politics on the internet.

6. From the show Dossier de l'écran (Organisation de radiotelevision française then Antenne 2) in the 60s-70s right up to shows like Apostrophes (Antenne 2) or Droit de reponse (TF1) in the 80s, we have seen that the presence of political personalities as guests was not limited to just political shows.

7. For more information on the concept of the "dispositive" derived from the work of M. Foucault, see Noël Nel (1998) who discussed this filiation and how it was used to analyze television. 
8. The audience is pre-conditioned by the warm-up presenter or comedian who actually incites them to ask for spectacular moments.

9. However journalists always intervene to keep discussion moving through directives particularly aimed at limiting the use of figures and speeches which are too long or too technical. 10. We shall use this title to refer to all programmes which have two parts in reality - Vivement dimanche (in the afternoon) and Vivement dimanche prochain (in the evening before the news). In this file, please see the article by B. Lafon on the contents of this show.

11. The "forum-style" shows and more generally laymen taking part in political shows appeared a way of avoiding people getting "tired" of political discourse. On this point, see É. Darras (1999), Sébastien Rouquette $(2001,2002)$ and P. Lefébure (2005).

12. In this file, our aim was not to argue one way or the other on the democratic relevance of politics being included in entertainment shows. On this particular point we refer readers to the synthesis of Anglo-Saxon debates and analyses presented by É. Neveu (2001, 2012) and the exchange between Kees Brants and É. Neveu (2003) sums up the opposition of these two viewpoints on diverse forms and different contexts (the Netherlands for the former and France for the latter) at a time when these forms have only existed for a few years. On this point, also see Liesbet Van Zoonen (2004).

13. See Apolline de Malherbe (2007) on the advantages of taking part in entertainment shows to become better known and reach a wider audience, This author's data shows that even before the first conversational shows, certain political personalities took part in many programmes of all kinds and continued to do so afterwards. J. Lang - Culture Minister (1981-1986), Culture and Communication Minister (1988-1992) then Education Culture Minister (1992-1993) under the presidency of François Mitterrand - took part in 33 shows before conversational shows were launched, appearing on Tout le monde en parle as early as 1999 and taking part in 75 entertainment shows in the period running from 1986-2006 (ibid. : 223-228).

14. By "institutionalization", we are referring to the fact that despite shows being cancelled or changed, this kind of programme now seems a definitive fixture in the schedules.

15. Today there are basically four talk-shows who invite politicians to appear - Le Grand Journal and Le Petit Journal (Canal +, different shows since September 2011), Salut les Terriens (Canal +) and On n'est pas couché (France 2).

16. In France, there are rules on television timing in the campaign in the audiovisual media based on principles of fairness to make sure candidates get exactly the same amount of airtime to speak. On this point, see the website of the French Conseil Superieur de l'Audiovisuel (CSA). The major national channels' regulations stipulate that there must be programmes with political guests without mention of the form of the shows. Thus the CSA made the private channel TF1 broadcast "political information magazines regularly during prime time". Access: http:// www.csa.fr/Television/Les-chaines-de-television/Les-chaines-hertziennes-terrestres/Leschaines-nationales-gratuites. Consulted on 01/10/13.

17. In the conversational formula political guests share the screen with entertainment personalities (often from the mainstream) and avoid a dual relationship (which was the case with Le Vrai Journal and En aparte on Canal +).

18. There has been a multiplication of mainstream theme-based channels (digital terrestrial television, distribution by internet access providers) whose output is largely made up of political exchanges (non-stop news channels, parliamentary channels) so the overall volume of programmes with political guests seems much more scattered than over the schedules than in the preceding period (Le Foulgoc, 2007; Eschstruth, 2007).

19. Unsurprisingly, classical political shows on major channels get the best audiences when there is an election (particularly the presidential election) and when they invite the most popular candidates in that competition. Outside elections, audience ratings generally depend on the 
guest, the prior interest in the show, its links with the political agenda and finally on competing programmes.

20. According to the advertising executive Jacques Séguela speaking in the documentary La political communication sous la Cinquième Republique (Gaillard, 2005, France 5) "showing off on Michel Drucker's show [...] is a must if you want to be the French President".

\section{AUTHORS}

\section{PIERRE LEROUX}

Centre de recherche sur l'action politique en Europe Institut d'études politiques de Rennes

Université catholique de l'Ouest/L'Université Nantes Angers Le Mans

F-49000

pierre.leroux@uco.fr

\section{PHILIPPE RIUTORT}

Groupe d'analyse politique

Université Paris Ouest Nanterre La Defense

F-92000

riutortp@yahoo.fr 